\title{
Changes in Grassland and Their Impact on Milk Production in Poland in the Context of Environmental Protection
}

\author{
Piotr Bórawski ${ }^{1 *}$, Wojciech Gotkiewicz ${ }^{1}$, Aneta Bełdycka-Bórawska ${ }^{1}$, \\ Elżbieta Jadwiga Szymańska², Agnieszka Brelik ${ }^{3}$, \\ Jayson K Harper ${ }^{4}$, James W Dunn ${ }^{4}$
}

\author{
${ }^{1}$ University of Warmia and Mazury in Olsztyn, Faculty of Land Management and Agriculture, \\ Department of Agrotechnology, Agricultural Production Management and Agribusiness, Olsztyn, Poland \\ ${ }^{2}$ Warsaw University of Life Science-SGGW, Faculty of Economic Sciences, Department of Logistics, Warsaw, Poland \\ ${ }^{3}$ West Pomerania University in Szczecin \\ ${ }^{4}$ Pennsylvania State University, Faculty of Agricultural Sciences, Department of Agricultural Economics, \\ Sociology, and Education, University Park, Pennsylvania, USA
}

Received: 25 April 2019

Accepted: 14 June 2019

\begin{abstract}
The objective of our paper was to present changes in grassland in Poland and their impact on milk production in Polish agriculture. This topic is very important because Poland increased its milk production after integration into the European Union. At the same time, the area of grassland decreased. This caused the appearance of some environmental problems. More land became devoted to other usage such as roads and business. During 2007-2017 the area of permanent meadows in Poland (-3,8\%), and pastures $(-4,8 \%)$ decreased. In 2005-2017, although cow numbers decreased $25,8 \%$, milk production increased $11,83 \%$ and milk yield per cow increased 50,2\%. The changes in milk production caused concentration of this production mainly in three woivodeships in Poland: Podlaskie, Mazowieckie and Wielkopolskie. The situation in the milk market was created by many factors, among which elimination of the quota system is very important. This led to more milk production but allowed farmers to increase exploitation of grasslands.
\end{abstract}

Keywords: grassland, milk production, environment

\section{Introduction}

Anthropogenic changes in the environment have resulted in the sixth major extinction of species in the

*e-mail: pboraw@uwm.edu.pl history of the Earth and widespread changes in the global distribution of organisms that affect ecosystem processes and reduce the resistance of ecosystems to environmental changes. This process has had profound consequences in the case of services that people derive from the environment [1]. Between 1900 and 2015, the geographical range of 177 of the most recognized 
mammalian species decreased by more than 30\%, while more than $40 \%$ of species experienced serious population decreases $(>80 \%)$. It is estimated that $42 \%$ of the 3623 species of terrestrial invertebrates and $25 \%$ of the 1306 species of marine invertebrates placed in the International Union for Conservation of Nature (IUCN) Red List of endangered species have been classified as threatened with extinction [2]. The extinction and emergence of new species is a natural process. The problem however, comes the pace of this phenomenon. It is estimated that the extinction of species in the world without humans progressed at the rate of one species per five years. Currently, it is said that four species die daily in Brazil [3].

The Rio Summit in 1992 and, consequently, the Convention on Biological Diversity, increased global awareness of the importance of sustainable development for the protection of wilderness. Agriculture is an inseparable element of this phenomenon, because agricultural practices can potentially destroy, protect or create biodiversity - especially in the case of grasslands, which are considered potential habitats rich in plant, animal and microorganism species [4]. Unfortunately, for a long time the agri-environmental policy of the European Union was largely focused on mitigating the harmful effects of agricultural intensification, and relatively small support was allocated to the development of sustainable agricultural systems that are socially and economically attractive to farmers and that introduce land management practices beneficial for wilderness [5].

As mentioned above, one of the functions of permanent grassland (beyond predictive) is to maintain the optimal level of biodiversity in the agricultural landscape, ensuring ecological stability of multi-species, meadow-plant communities, and being a refuge of many species of animals - including rare and legally protected. However, it should be emphasized that this mainly concerns meadows and pastures of a natural and semi-natural character [6-8]. It is estimated that there are only 70,000 species and living organisms, including about 3,000 species of vascular plants and 33-47,000 animal species in Poland. This is determined by the traditional agricultural economy (especially in regions with a mosaic-like structure of agriculture), the high share of permanent grasslands, and the occurrence of semi-natural areas, including wetlands - a large part of which are located in Natura 2000 areas. Almost half of the types of plant communities occurring in Poland are in habitats in rural areas, and the main refuge for biodiversity is extensive meadows, pastures, ponds and forests [9]. Out of 81 natural habitat types from Annex I of the Habitats Directive occurring in Poland, at least 16 are associated with arable land. Among them are five types of habitats of priority importance [10]. Among endemic vascular plants in Europe, $18.1 \%$ are associated with grassland habitats - almost twice as much as in forests, although the latter cover much more land area [11].
One of the indicators of the state of biodiversity in areas used for agriculture in the European Union is the index of abundance of common agricultural landscape birds: the FBI or farmland bird index [12, 13]. From among 22 indicator species, all are directly or indirectly connected with permanent grassland. According to Stasiak et al. [14], studies carried out as part of monitoring the impact of agri-environmental programs on avifauna showed a significantly positive impact of the share of permanent grassland on the average number of birds from the FBI's "basket." Unfortunately, many years of research have documented a steady decline in the bird population in agricultural areas throughout Europe.

This pattern of long-term decline was not visible in bird communities of other habitats, which suggests that the decline in bird population in agricultural areas was caused by factors specific to this habitat, and not part of the general decline in bird population on the continent [15].

The same situation takes place in Poland, where, according to recent studies, the FBI index reached its lowest level in 2017 in the entire 18-year monitoring period (Fig. 1). For the first time, the value of this indicator fell to $80 \%$ of the value obtained by the indicator in the reference year (2000). This confirms once again that birds associated with the agricultural landscape have been in a disadvantageous and constantly deteriorating situation for a long time. This is even more disturbing if one takes into account the fact that strong downward tendencies are also recorded among several field species not included in the FBI [16].

The preservation of extensively used, large grassland areas also has a significant, positive impact on insect populations, some of which are extremely important pollinators, as demonstrated by studies conducted, among others, in the Czech Republic, in Sweden, in Finland and even in Japan [17-20]. In Austria, 1041 species of insects were found in habitats associated with grasslands, of which up to $85 \%$ were endangered species found in the "Red Book" [21].

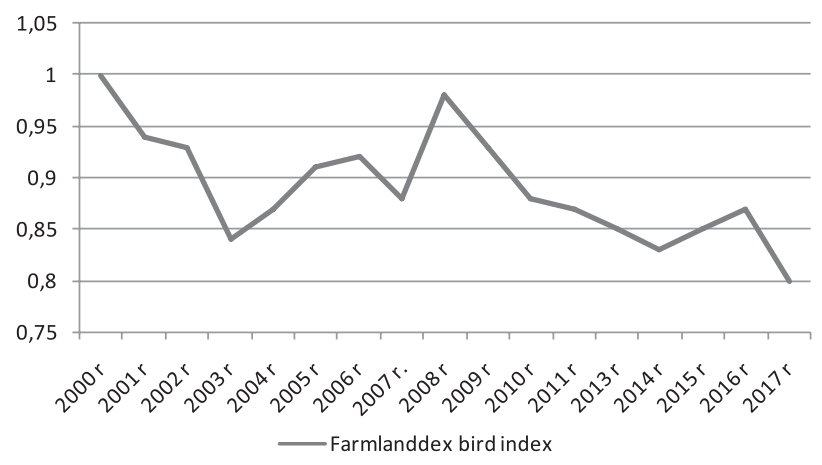

Fig. 1. Changes in the value of the index number of common birds of the agricultural landscape of the farmland bird index (FBI) and the index of the abundance of common forest birds, forest bird index 34 (FBI34), in 2000-2017. 
Permanent grasslands are also key areas for preserving the natural values of rural areas - buffer zones for surface waters and areas enhancing water retention (counteracting floods) [22-24]. The ability to create a mundane, relatively compact coat by grassy communities means that they have a greater impact on the composition of the atmosphere than other plant communities. Concentrations of $\mathrm{CO}_{2}$ carbon dioxide (which is about $50 \%$ heavier than air) is higher in the above-ground layer, which facilitates its collection by meadows and pastures. An average agricultural crop uses about $150 \mathrm{~kg}$ of $\mathrm{CO}_{2}$ per ha per day. From other findings, it appears that a similar grassland expels $100 \mathrm{~kg}$ of $\mathrm{O}_{2}$ per ha from the atmosphere during the day [25].

Another important function of permanent grasslands is their prevention of erosion, which has a negative impact on soil fertility, suitability for cultivation, and contributes to the pollution of surface waters. Without the permanent cover of plants, the amount of washed soil rises from a few to a dozen $\mathrm{t} / \mathrm{ha} /$ year, which reduces the thickness of the humus layer. The permanent and firmly rooted turf of permanent grassland also mitigates the effects of wind erosion [26].

Unfortunately, in 1993-2011, the area of permanent grassland decreased by $6.4 \%$ in the old EU countries and by $11.8 \%$ in the new member states [27]. Many European grasslands of high natural value are still threatened by the change of land use that previously created and maintained them, i.e., intensification (including increasing cattle density), abandonment and afforestation [28, 29].

On the level of biodiversity of grasslands, apart from environmental factors, there is also a way to use them [30]. This particularly applies to mowing and grazing. The abandonment of these practices is the cause of secondary succession manifested by gradual overgrowing of unused areas, e.g., through bushes and trees, which is associated with the loss of the nature of the open landscape and the withdrawal of animal species associated with it. This problem is increasingly affecting grassland in large river valleys in Poland [31-33]. The question of the use of permanent grassland in the case of birds that use the grasslands for nesting places or constitutes their basic and, in many cases, only food base, is extremely interesting. On the one hand, it is known that the intensification of agriculture was one of the most important factors contributing to the decline in the population of many species of birds (partridge, corncrake, etc.) [34, 35]. Research conducted in the United Kingdom, however, showed that there is no unambiguous answer to the question of which system of use is the most desirable, as it depends, among others, on the season, bird species and behavior, type of use, size of the plot, and the occurrence of natural lands $[5,36]$.

Milk production is an important part of Polish, European, and world agriculture. However, with the production of milk some issues appear. The first is the problem with the environment. The increasing production of milk requires more grassland. Each year the area of grassland in Poland is decreasing. More agricultural land is diverted to other uses, including roads and the development of businesses.

The development of agriculture was dependent on industrialization. It included the inflow of new machinery, technologies and investment in agriculture. Conventional farming is based on an agricultural production increase based on mechanization and chemical fertilizers. A lack of knowledge about the negative consequences of intensive farming on the natural environment contributed to worsening food quality and animal welfare. For a long period of time the economic issues were more important than the environmental ones. Such a situation was typical for dairy farms because their owners invested in modernization, new varieties of dairy cows and new fodders. Milk producers are interested in increasing a cow's milk yield and did not foresee the negative consequences of such activities. Unfavorable phenomena associated with the increase in milk yield of cows include metabolic diseases, udder diseases, deterioration of milk quality, increases in somatic cell content, poorer chemical composition of the milk, problems with sagging and shortening the life of cows. Higher milk yield can lead to limb damage and difficulties in their calving. The research carried out by Runowski [37] proves that if there is higher individual productivity in cows, then the longer period from calving to effective insemination appears. This means nothing but a deterioration of ecological and ethical goals. The life of cows is shortened due to the occurrence of numerous diseases associated with excessive exploitation of animals. Maximizing the economic effects in dairy farming can promote deterioration of ecological and ethical goals.

Such problems are not typical for organic dairy farming, which produces milk using home-produced fodder. Moreover, the animals live longer as they are not exploited so intensively. Raising ecological cows favors improved cow health, a lower rate of death loss, and lower costs of herd replacement [38]. But the most important problem is lower economic efficiency and productivity of organic dairy farming in comparison to conventional.

This article is organized as follows. First, we present an introduction. Second, we describe the efficiency of rapeseed production. Next, we present our aims and methodology. The next part of our paper deals with the problem of meadows and pasture decreases. Later, we present changes in milk production. The final part is the conclusion.

\section{Material and Methods}

The aim of our paper was to analyze changes in the grassland in Poland and its impact on milk production in Poland in 2005-2017. 
The authors of the paper wanted to address following questions:

1. What are the changes in meadows and pasture areas?

2. How have milk production, milk per cow yield and cow numbers changed?

3. Have the changes in pastures and meadows had an impact on milk production, cow numbers and milk per cow?

We used main statistical office data to show the changes and presented the results using descriptive, tabular, and graphical forms to describe the changes. Our source of information was also the milk market [39].

We also wanted to answer the question if the area of meadows and pastures have an impact on milk production, milk yields and cow numbers. Pearson correlation coefficients were calculated, allowing us to determine the dependence of variables. In order to determine the impact of macroeconomic variables on the efficiency of agriculture, a regression method was used. Due to the fact that between the surface of meadows and pastures, a high correlation coefficient of interrelations between variables was observed and we used linear regression, which is described by the following formula [40]:

$$
\mathrm{y}=a * x+b
$$

$a$ - directional factor of the straight regression

$b-$ free expression of a simple regression

...where:

$$
\mathrm{a}=\frac{\sum\left(X_{i}-\dot{\mathrm{X}}\right) *\left(Y_{i}-\dot{\mathrm{Y}}\right)}{\sum\left(X_{i}-\dot{\mathrm{X}}\right)^{2}}=\frac{\operatorname{cov}(X, Y) x^{2}}{\sigma \frac{2}{x}}=r_{x y} * \frac{\sigma_{y}}{\sigma_{x}}
$$

$b=\dot{Y}-a \dot{X}$

$X, Y_{i}$-variable values $X, Y$

$\dot{Y}, \dot{X}$ - average of variables $X, Y$

$\operatorname{cov}(X, Y)$ - covariance of variables $X i Y$

$\sigma_{x}, \sigma_{y}$ - standard deviations $X i Y$

$r_{x y}$ - correlation coefficient between $X i Y$

Variables were sequentially explained: $\mathrm{Y}_{1}$ (the cows heads), $\mathrm{Y}_{2}$ (milk production), $\mathrm{Y}_{3}$ (milk per cow). However, the explanatory variables were successively: $X_{1}$ (meadows area), $X_{2}$ (pastures area). We used the method of least squares to conduct the linear regression analysis.

\section{Results and Discussion}

Each year we can observe changes in land use worldwide. Generally more land is used for roads, businesses, and buildings and less land is devoted to agricultural production. Fan et al. [41] found that in China the rapid growth rate of forest land was in sharp contrast with the decrease of cultivated land. As Wang et al. claim [42], changes in the spatial pattern of land use alter the structure and function of ecosystems and then affect ecosystem services. That is why the EU has undertaken activities with a goal to preserve the most endangered species. The Natura 2000 network is designed to preserve valuable natural habitats across their entire natural range within the EU [43].

The permanent meadows are very important assets of farms, especially in milk production. They are a basis of fodder during the whole year. The intensive milk production is characterized by using chemical fertilizers, which cause from one side the development of grass production and increase problems with species on the other side.

The results in Table 1 present big changes in permanent meadows in Poland. All voivodeships in Poland recorded the decrease in the area of permanent meadows. Particularly high decreases have been observed in 2007-2017 in Dolnośląskie Voivodeship $(-6,8 \%)$, Opolskie Voivodeship (-9,5\%), Wielkopolskie Voivoedship (-6,2\%), and Podkarpackie Voivodeship $(-5,1 \%)$. The smallest decreases were observed in Podlaskie Voivodeship (-1,4\%), Świetokrzyskie Voivodeship (-2,1\%), and Mazowieckie Voivodeship $(-2,7 \%)$

Such changes in permanent meadows have an impact on natural habitat decreases. According to Brzank et al. [44], the effective maintenance of favorable status of natural habitat requires the better form of payments. According to the author, the CAP "greening" in current perspective (2014-2020) gives farmers a choice of the most appropriate management to increase biodiversity in farmlands.

Permanent pastures deliver fodders, especially during summer. Less effective milk production is based on cow feeding. Pasture grazing has a positive effect on grassland as it provides organic fertilizers, preserves soil and does not destroy organic matter and the organisms that live in these areas.

The area of permanent pastures is presented in Table 2. The analysis has confirmed the decrease of permanent meadows in Poland. Particularly high decreases have been observed in 2007-2017 in Opolskie Voivodeship (-12,4\%), Wielkopolskie Voivodeship $(-10,2 \%)$ and Lubelskie Voivodeship (-7,8\%). The smallest decreases have been observed in Podlaskie Voivodeship (-1,9\%), Małoplskie Voivodeship (-2,5\%) and Lubuskie Voivodeship $(-3,4 \%)$.

The effects of the decrease of permanent meadows and pastures in Poland and other countries of the EU and world are the effects of human activity, forest clearance, and, to a lesser extent, burns and wetland drainage aimed at providing fodder for domestic livestock [44].

Milk production in a broader sense is conditioned by two factors. The first is the stock of dairy cows. According to CSO [45] in 2017, the number of dairy cows amounted to 2152.8 thousand heads, while in 2018, 2214 thousand heads, therefore the stock of dairy cows increased by $2.8 \%$ (Fig. 2). The largest dairy 


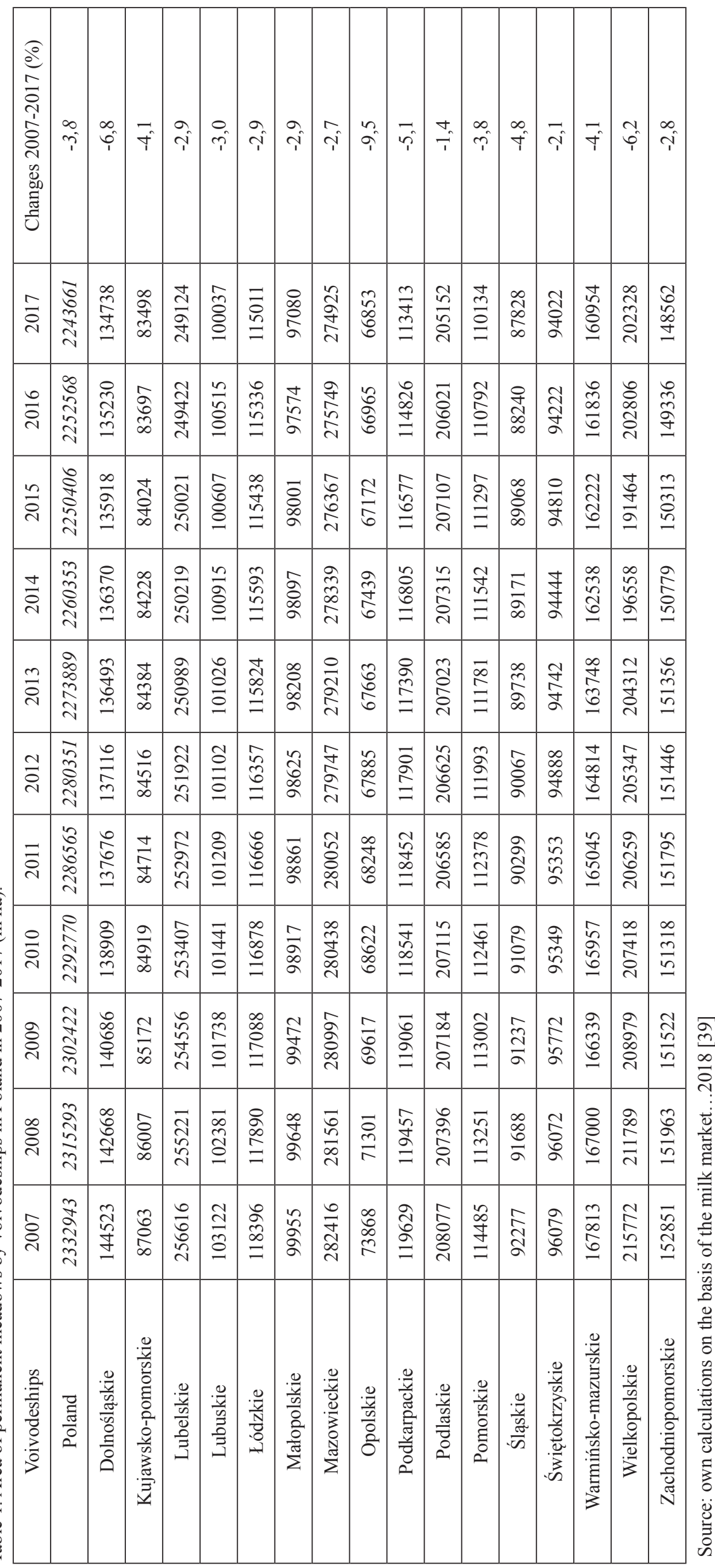




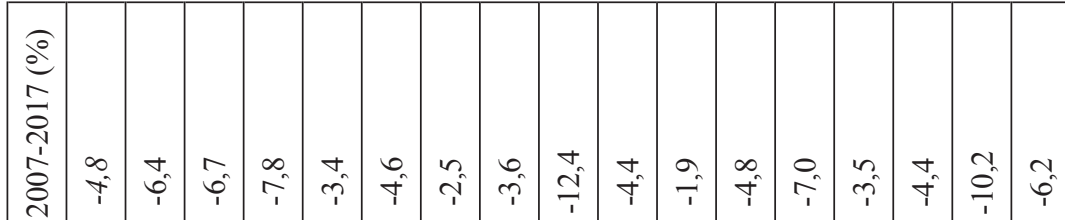
总

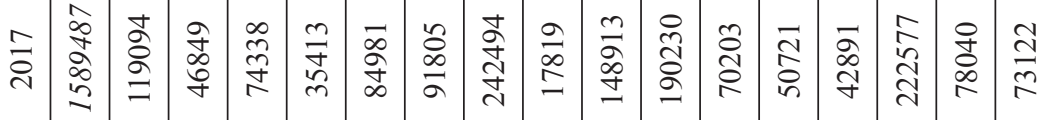

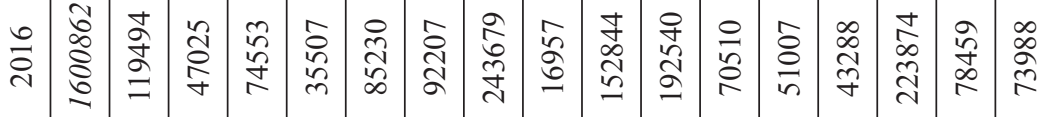

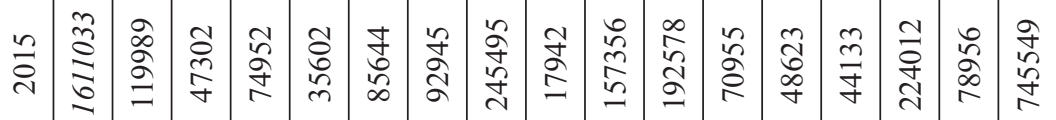

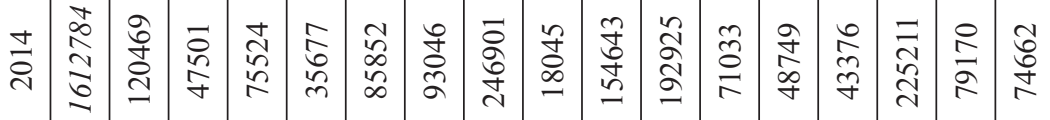

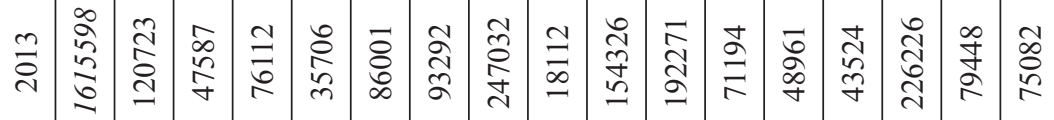

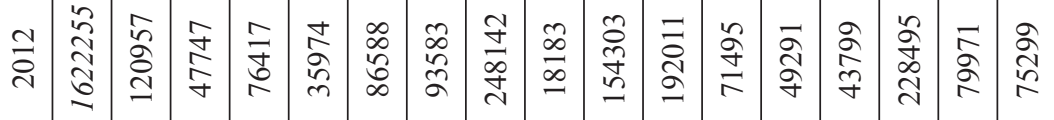

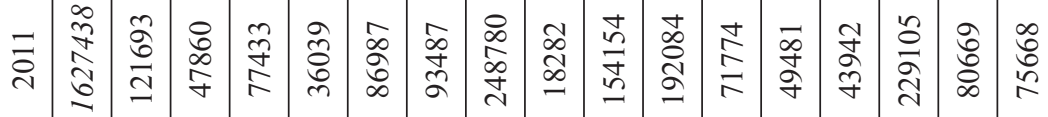

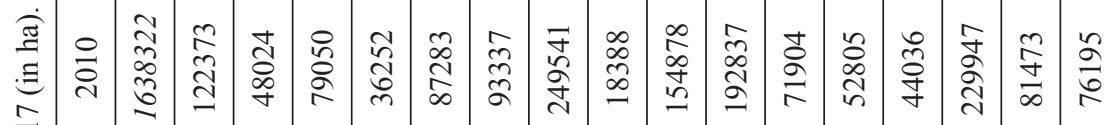

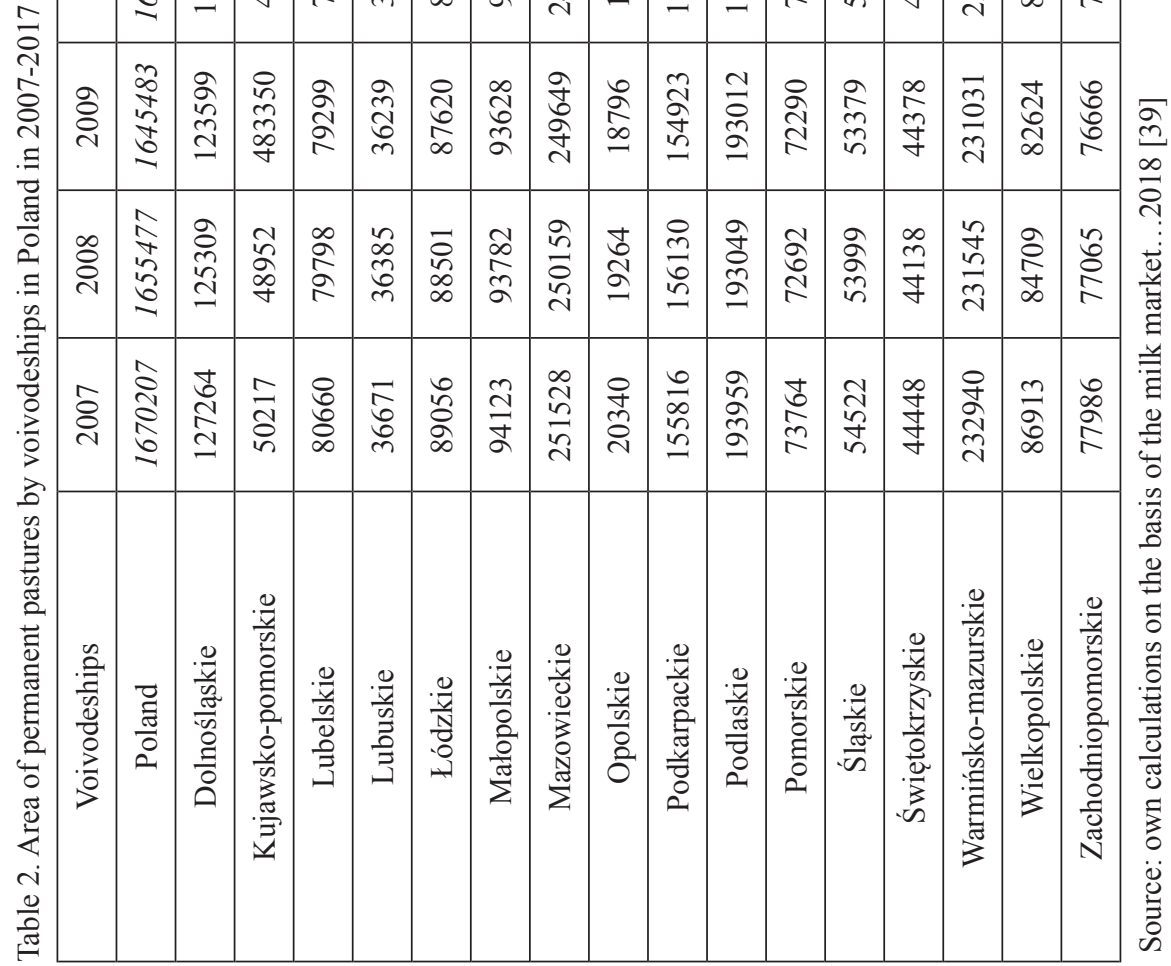




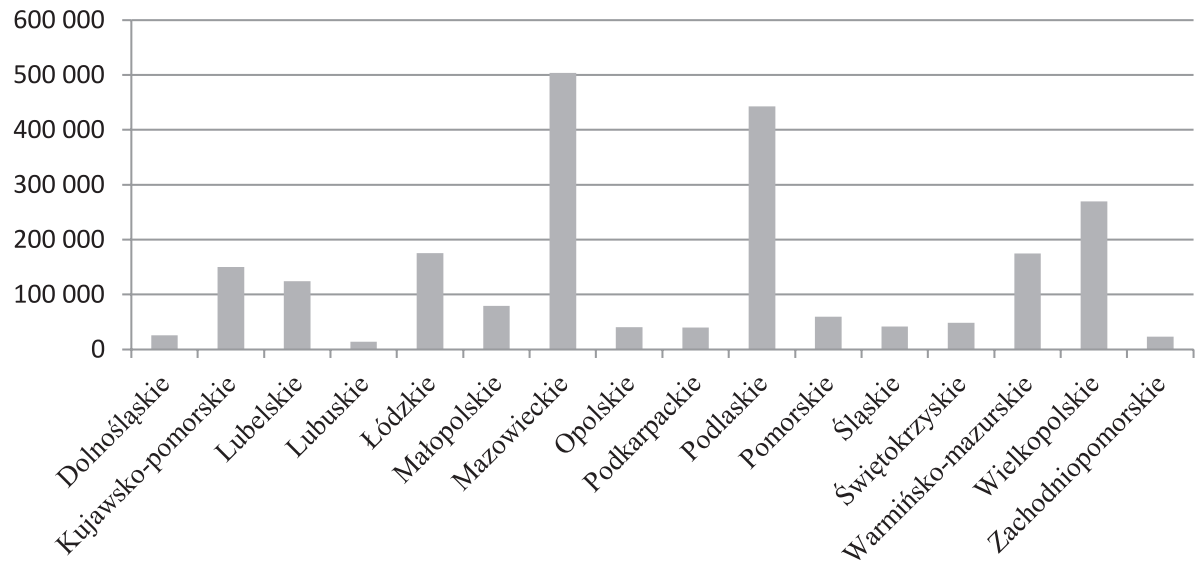

Fig. 2. Population of dairy cows according to voivodships in December 2018 in Poland (source: CSO 2018 [45]).

cow numbers was recorded in Mazowieckie Voivodship (503,900 heads), while the smallest change occurred in Lubuskie Voivodeship (14,000 heads). In 2007-2017, the cow population decreased (-25.8\%) [46]. Compared to 2014 and 2015, the number of cows in 12 provinces decreased from $1 \%$ to $24 \%$ in 2017 . The most was in Lubuskie Voivodeship, totaling almost 1/4. In the Warmińsko-Mazurskie, Pomorskie and Lubuskie voivodships, the population was reduced by 2.4-3\%. In the Wielkopolskie and Podlaskie voivodships, the number of dairy cows increased by approx. $4 \%$. More and more small and low-efficiency farms are withdrawing from milk production, which leads to a reduction in domestic herds. In large farms, where the production potential was limited by milk quotas, the stock will increase. Reductions can also counter the subsidies for farmers keeping herds from 3 to 30 cows [47].

The largest concentration of milk production occurs in Wielkopolskie, Podlaskie and northern voivodeships of Mazowieckie Voivodeship. Considerable fragmentation of the herd is a characteristic feature of dairy cattle breeding in Poland. About 250,000 farms maintains only 1-2 cows. Therefore, the average size of the herd does not exceed 5 cows. Within 8 years, the concentration of cow breeding has not changed. The main factors in the area of milk production were historical conditions [46].

The current situation on the milk market is caused by the increase in the stock. The year 2018 was one of the best in terms of price per liter of milk produced. In the last month of 2018, farmers received an average of PLN 1.40 per liter. The highest price (PLN 1.47 per liter) was received by farmers in Podlaskie Voivodship. In this region, the main recipients are OSM Piątnica, which has been recording the highest price for years. The next recipient of milk is SM Mlekovita, which has a large share on the EU market and exports a lot of dairy products to countries outside the community. The preparations include: butter, cheese and powdered milk. In turn, the lowest price per liter was received by producers from Małopolska Province (PLN 1.26 per liter). This is due to the small supplies and herd sizes [45].

The current situation in the milk market is quite promising. According to the European Commission's analysts, drought in the eastern part of Europe and New Zealand will result in the lack of a feed base, which will reduce supplies. Poland will not be affected that much. Another issue is the decreasing stocks of skim milk powder (SMP). The international production can be complemented on the market by a $20 \%$ increase in imports of dairy products from the United States [45].

The reverse situation on the milk market was after the release of milk quotas in force from 1984 to 2015. Lack of restrictions on milk production caused an increase in the supply of raw material and there was no market for it. One of the activities of the European Commission was the intervention purchase of milk powder, which slightly improved the situation on the market. The abolition of milk quotas caused an increase in milk deliveries to dairies by $2.2 \%$. The share of milk delivered to the dairy processors in 2015 increased to $83 \%$ in comparison to 2005 [46]. This is a consequence of the high profitability of production in 2013-2014, and preparations for the abolition of milk quotas. Producers who exceeded the amount had to pay significantly higher penalties. A significant facilitation is the possibility of spreading the repayment for 3 years, which protects many households from bankruptcy. This situation will reduce the profitability of production in 2015-2017 [47].

The second factor conditioning milk production is the milk yield of cows, which is systematically growing. This results mainly from breeding progress. Herds are genetically improved by insemination with high-quality semen and the purchase of animals from abroad. The average annual cow milk production in 2010 amounted to 4487 liters, while in 2017 this value amounted to 5687 liters (a 26.7\% efficiency increase). 


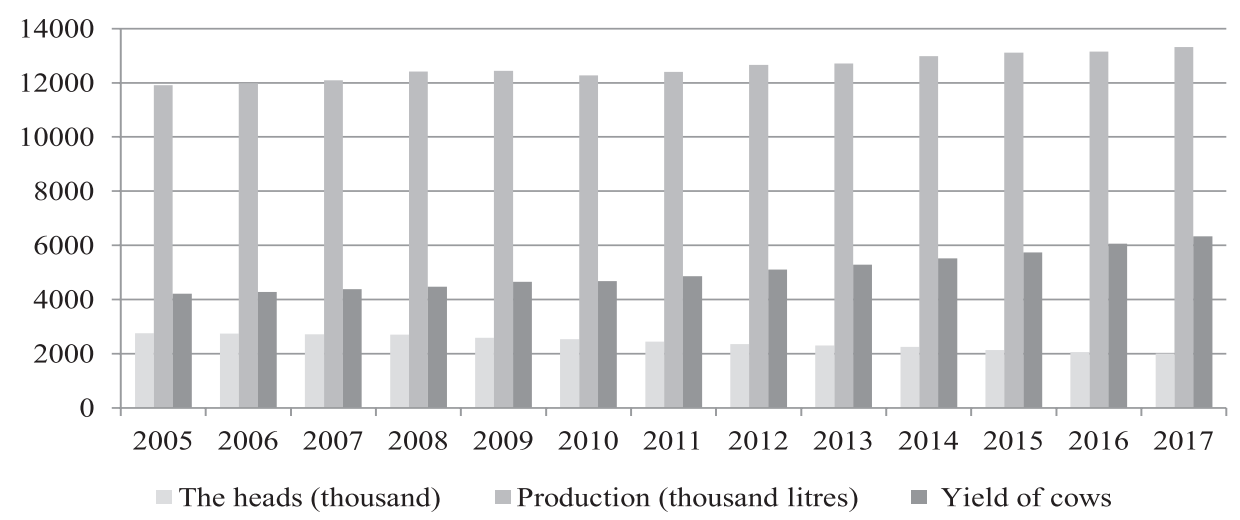

Fig. 3. Heads, production and milk yield of cows in Poland (thousands); source: own elaboration on the basis of the milk market [39].

In the corresponding period, domestic production of cow's milk increased $11.6 \%$ [45].

In 2016, the milk yield of cows increased by $5.5 \%$ compared to the previous year. Technological progress contributes to the growth of cow's milk yield. This is evidenced by the increasing number of cows under the control of the animal's usability. In 2014, the control covered 20 thousand farms. The improvement of milk production is limited by the physical and economic difficulties associated with obtaining good quality feed. It is caused by drought, which occurred in 2015. Drought particularly affected central and northeastern Poland. The hay harvest was much lower. Poor corn yield caused lower silage quality. Despite the difficult situation of many farms, average cow productivity in Poland was 6235 liters per cow in 2017. It is still lower than in the EU-15 countries, where the productivity is at the level of $7267 \mathrm{~kg}$. It is estimated that future milk production will increase. However, the increase of milk production may cause serious environmental problems and is not consistent with sustainable development. This order is based on three following components: social, economic and environmental [48]. Intensive milk production can have a negative impact on the environment, which is why the more effective methods of conservation biodiversity, particularly in lands used for agricultural production and rural areas, should be introduced [49].

At the same time, in 2005-2017 milk production increased by nearly $12 \%$ as a result of improved cow productivity, which in 2005-2017 increased by nearly $50.2 \%$ (Fig. 3). On the one hand, this fact should be assessed positively, on the other, however, one should be aware that Poland is a country with lower milk yield in relation to the United States or many countries in the EU [46].

The authors of the paper have analyzed the descriptive statistics for milk and permanent meadows and pastures. Our analysis has found that the highest coefficient of variation was observed in yields of cows $(13,82 \%)$ and the heads $(11,01 \%)$ and milk production $(3,67 \%)$. The area of pastures $(1,94 \%)$ and meadows $(1,50 \%)$ had a lower coefficient of variation (Table 3$)$.

The average yields of cows were 5041 liters in 2005-2017, the minimum was 4213 and the maximum was 6330 liters. The average heads were 2425,8 thousand and the maximum was 2754 thousand head and the minimum was 2000 thousand head.

Kurtosis and skewedness are asymmetry measures. Kurtosis reached negative values, indicating that they were different in the analyzed period in relation to the mean. Skewedness is positive if the tail on the right side of the distribution is longer or fatter than the tail on the left side. Only the heads of cows achieved negative skewedness.

Research on the trends of changes in the milk market in Poland shows that milk production is also important in creating the value of global agricultural production. Due to the importance of this raw material for agriculture, it is necessary to evaluate the organization

Table 3. Descriptive statistics of milk production, heads and cows field and area of meadows and pastures.

\begin{tabular}{|c|c|c|c|c|c|c|c|c|}
\hline Specification & Mean & Median & Minimum & Maximum & Std. Dev. & C. V. & Skewedness & Curtosis \\
\hline Yields of cows & 5041,2 & 4854,0 & 4213 & 6330 & 696,78 & 13,82 & 0,517 & $-0,985$ \\
\hline The heads & 2425,8 & 2446,0 & 2000 & 2754 & 267,07 & 11,01 & $-0,228$ & $-1,318$ \\
\hline Milk production & 12570 & 12439 & 11905 & 13314 & 461,16 & 3,67 & 0,152 & $-1,180$ \\
\hline Area of pastures & 16355 & 16274 & 15895 & 16921 & 31668 & 1,94 & 0,404 & $-0,951$ \\
\hline Area of meadows & 22903 & 22866 & 22437 & 23425 & 34463 & 1,50 & 0,232 & $-1,247$ \\
\hline
\end{tabular}

Source: own elaboration on the basis of the milk market 2018 [39] 
Table 4. Regression analysis.

\begin{tabular}{|c|c|c|c|c|c|c|}
\hline Specification & Coefficient & Std. error & t-ratio & p-value & R-squared \\
\hline \multicolumn{7}{|c|}{ The heads } \\
\hline Meadows & 0,0082 & 0,0033 & 2,446 & 0,0345 & 0,954 \\
\hline Pastures & $-0,000$ & 0,0037 & $-0,225$ & 0,826 & \\
\hline \multicolumn{7}{|c|}{ Milk production } \\
\hline Meadows
\end{tabular}

Source: own elaboration on the basis of the milk market 2018 [39]

and production economics, taking into account the current trends and competitive position of Polish farms. The analysis of the calculated coefficients correlation (Table 4) shows that there is a statistically significant and very strong dependence of the number of cows, milk yield of cows and milk production on the size of meadows and pastures. At the same time, the production of milk depends on the size of meadows and pastures, and milk yield is the least important.

The correlation coefficients confirmed the positive relationship between variables. A large share of meadows and pastures in farms has a positive impact on the organization of their use. It allows for keeping a certain number of animals (especially cattle) with slightly lower yields of hay and pasture feed resulting from restrictions on farms, including organic farms.

Finally, we have conducted the regression analysis to measure if meadows and pastures have an impact on cow numbers, milk production and milk yields (Table 4). Our analysis proved that the area of meadows had an impact on cow numbers, which means that the decrease of meadows area had an impact on the decrease of the heads of cows. All the models were fitted well because the R-squared was high.

Data analysis shows that there is a statistically significant relationship between the cow population and the pasture area. As the number of cows increases, the surface of the pastures increases (Table 5). This is a natural phenomenon conditioned by the nutritional needs of the animals. This dependence can be written with Eq. 1:

$$
\mathrm{Y}=0.008719 \mathrm{x}-11789.6 \mathrm{r}^{2}=0.927
$$

A similar relationship occurs between the cow's population and the surface of meadows, and is reflected by Eq. 2 :

$$
Y=0.007528 x-14781.6 \quad r^{2}=0.961
$$

A different situation concerns the relationship between the milk yield of cows and the surface of meadows and pastures. As the milk yield of cows increases, the area of pastures decreases. This is probably due to the cow feeding system. This relationship is illustrated by Eq. 3 .

$$
Y=-0,02534 x+46388.3 \quad r^{2}=0.904
$$

The same dependence applies to the milk yield of cows and meadows. You can save it with Eq. 4:

$$
Y=-0.0216 x+54461.89 \quad r^{2}=0.914
$$

Table 5. Correlation analysis.

\begin{tabular}{|c|c|c|c|c|c|}
\hline & Meadows & Pastures & Number of cows & Milk production & Milk yield of cows \\
\hline Meadows & 1,000000 & 0,999933 & 0,964928 & 0,985929 & 0,906409 \\
\hline Pastures & 0,999933 & 1,000000 & 0,966644 & 0,984709 & 0,903293 \\
\hline Number of cows & 0,964928 & 0,966644 & 1,000000 & 0,910929 & 0,767856 \\
\hline Milk production & 0,985929 & 0,984709 & 0,910929 & 1,000000 & 0,963111 \\
\hline Milk yield of cows & 0,906409 & 0,903293 & 0,767856 & 0,963111 & 1,000000 \\
\hline
\end{tabular}

Source: own calculation 
All regression equations presented have a high coefficient of determination $\left(\mathrm{r}^{2}\right)$, which indicates a high level of fit of the models.

The Polish dairy sector has been changing after the accession to the EU. The changes are typical for countries that introduced Common Agricultural Policy (CAP) and include agriculture, food and rural areas. These changes include legislation of safety and quality of food and environmental standards and international trade [50]. Changes that appeared in the Polish dairy sector are typical for agriculture as a whole and include [51]:

- Reduction of farm numbers.

- Decline in the employment in agriculture.

- Concentration of production.

\section{Conclusions}

The aim of the paper was to analyze changes in the land, mainly grassland in Poland and its impact on the milk production in Poland in 2005-2017. Land is a basic and crucial resource for economic development. The dynamic change of land use is an important element of rational planning of land resources.

Our results indicate big decreases in the area of permanent meadows and pastures in Poland in 2005-2017. These results may indicate possible problems for the environment. The population of birds, which are natural inhabitants, has decreased as a result of intensive milk production in rural areas and exploitation of grasslands. This confirms that birds living in the agricultural landscape have been at a disadvantageous and constantly deteriorating situation for a long time.

The coefficient of variation informs us that the highest coefficient of variation was observed in milk yields of cows $(13,82 \%)$ and the heads $(11,01 \%)$ and milk production $(3,67 \%)$. Such serious changes created not only income increases of farms engaged in milk production, but also a concentration of milk in some voivodeships in Poland. Podlaskie, Mazowieckie and Wielkopolskie voivodeships are the regions with the biggest milk production and concentration.

On the other side, the population of dairy cows decreased in Poland while the average milk yield by cow increased. This was the effect of using more productive cow species and more intensive milk production. Closed cow breeding in cowsheds has created bigger milk production from one side, but the natural inhabitant's population has decreased.

Our analysis of regression points out that the decrease of meadow area had an impact on the decrease of cow numbers. In the analyzed time 2005-2017, the production of milk increased almost $12 \%$ and cow yields almost $50 \%$. This could only be achieved by better and more effective cow breeds and a more effective system of feeding. However, these changes have created the problem of meadows and pasture exploitation.

\section{Acknowledgements}

This article was written by the project funded by the National Science Centre in Poland allocated on project OPUS 15, project No. 2018/29/B/HS4/00392. The Authors of the paper would like to thank the two anonymous reviewers for their comments, which helped to improve this paper.

\section{Conflict of Interest}

The authors declare no conflict of interest.

\section{References}

1. CHAPIN III F.S., ZAVALETA E.S., EVINER V.T., ROSAMOND L. NAYLOR R.L., VITOUSEK P.M., REYNOLDS H.L., HOOPER D.U., LAVOREL S., SALA O.E., HOBBIE S.E., MACK M.C., DÍAZ S. Consequences of changing biodiversity, Nature, 405, 236, 2000.

2. CEBALlOS G., EHRLICH P.R., DIRZO R. Biological annihilation via the ongoing sixth mass extinction signaled by vertebrate population losses and declines. Proc Natl Acad Sci U S A. 2017 Jul 25; 114 (30), 6090, 2017.

3. PRANECKI K., SADOWSKI M. Międzynarodowa ewolucja ochrony środowiska (The international evolution of environmental protection). Wydawca LAM Wydawnictwo Akademii Finansów, 185, 2010 [In Polish].

4. PLANTUREUX S., A. PEETERS A., MCCRACKEN D. Biodiversity in intensive grasslands: Effect of management, improvement and challenges. Agronomy Research 3 (2), 160, 2005.

5. VICKERY J.A., TALLOWIN J.R., FEBER R.E., ASTERAKI E.J., ATKINSON P.W., FULLER R.J. The management of lowland neutral grasslands in Britain: effects of agricultural practices on birds and their food resources. Journal of Applied Ecology 38, 650, 2001.

6. BURCZYK P., GAMRAT R., GAŁCZYNSSKA M., SARAN E. Rola trwałych użytków zielonych w zapewnieniu stanu równowagi ekologicznej środowiska przyrodniczego (The role of grasslands in the providing ecological sustainability of the natural environment). Water-Environment-Rural Areas (VII-IX), 18, 3 (63), 30, 2018 [In Polish].

7. PÄRTEL M., BRUUN H. H., SAMMUL M. Biodiversity in temperate European grasslands: origin and conservation Grassland Science in Europe, 10, 5, 2005.

8. KOPACZ M. Funkcje trwałych użytków zielonych na obszarach górskich $\mathrm{w}$ kontekście zmian prawnogospodarczych. (The role of permanent grasslands in mountain areas in terms of legal and economic changes. Grassland Science in Poland, 18, 135, 2015 [In Polish].

9. GOŁĘBIEWSKA B., CHLEBICKA A., MACIEJCZAK M. Rolnictwo a środowisko. Bioróżnorodność i innowacje środowiskowe $\mathrm{w}$ rozwoju rolnictwa (Agriculture and the environment. Biodiversity and environmental innovations in agricultural development). Wyd. Wieś Jutra, 2016 [In Polish].

10. Prognoza oddziaływania na środowisko projektu Programu Rozwoju Obszarów Wiejskich na lata 20142020. Opracowanie wykonane na zlecenie Ministerstwa Rolnictwa i Rozwoju Wsi w ramach umowy nr 823/13. 
(Forecast of the environmental impact of the draft Rural Development Program for 2014-2020. The study was commissioned by the Ministry of Agriculture and Rural Development under contract number 823/13). Wyd. IUNG Puławy 2014 [In Polish].

11. HABEL J. CH., DENGLER J., JANIŠOVÁ M., TÖRÖK P., WELLSTEIN C., WIEZIK M. European grassland ecosystems: threatened hotspots of biodiversity. Biodiversity and Conservation, 22 (10), 2135, 2013.

12. BUTLER S.J., BOCCACCIO L, GREGORYC R.D., VORISEK P, NORRIS A. Quantifying The impact of land-use change to European farmland bird populations. Agriculture, Ecosystems And Environment 137, 350, 2010.

13. TRYJANOWSKI P., HARTEL T., BÁLDI A., SZYMAŃSKI P., TOBOLKA M., HERZON I., GOŁAWSKI A., KONVIČKA M., HROMADA M., JERZAK L., KUJAWA K., LENDA M., ORŁOWSKI M., PANEK M., SKÓRKA P., SPARKS T. H., TWOREK S., WUCZYŃSKI A., ŻMIHORSKI M. Conservation of farmland birds faces different challenges in Western and Central-Eastern Europe. Acta Ornithol. 46, 10, 2011.

14. STASIAK K., KUJAWA K., KROGULEC J., JOBDA $M$ (red.) Wpływ praktyk rolniczych na ptaki (Impact of agricultural practices on birds), OTOP Marki, 37, 2016 [in Polish].

15. DONALD P.F., SANDERSON F.J., BURFIELD I.J., VAN BOMMEL F.P.J. Further evidence of continent-wide impacts of agricultural intensification on European farmland birds, 1990-2000. Agriculture, Ecosystems \& Environment, 116, (4), 195, 2006.

16. CHODKIEWICZ T., NEUBAUER G., SIKORA A., ŁAWICKI Ł., MEISSNER W., BOBREK R., CENIAN Z., BZOMA S., BETLEJA J., KUCZYŃSKI L., MOCZARSKA J., ROHDE Z., RUBACHA S., WIELOCH M., WYLEGAŁA P., ZIELIŃSKA M., ZIELIŃSKI P., CHYLARECKI P. Monitoring ptaków Polski w latach 2016-2018 (Monitoring of Polish birds in 2016-2018). Biuletyn Monitoringu Przyrody 17, 55, 2018 [In Polish].

17. KONVICKA M., BENES J., CIZEK O., KOPECEK F., KONVICKA O., VITAZ L. How too much care kills species: Grassland reserves, agri-environmental schemes and extinction of Colias myrmidone (Lepidoptera: Pieridae) from its former stronghold. Journal of Insect Conservation, 12 (5), 524, 2008.

18. ÖCKINGER E., SMITH H.G. Seminatural grasslands as population sources for pollinating insects in agricultural landscapes. Journal of Applied Ecology, 44 (1), 59, 2007.

19. PÖYRY J., LINDGREN S., SALMINENJ., KUUSSAARI M. Responses of butterfly and moth species to restored cattle grazing in semi-natural grasslands. Biological Conservation, 122 (3), 470, 2005.

20. UCHIDA K., TAKAHASHI S., SHINOHARA T., USHIMARU A. Threatened herbivorous insects maintained by long-term traditional management practices in seminatural grasslands. Agriculture, Ecosystems \& Environment, 221, 160, 2016.

21. GŁODOWSKA M., GAŁĄZKA A. Wpływ rolnictwa ekologicznego na środowisko w koncepcji rozwoju zrównoważonego (Impact of Organic Farming on Natural Environment within the Concept of Sustainable Development). Wieś i Rolnictwo 2, (175), 153, 2017 [In Polish].

22. DEMBEK W. Problemy ochrony polskiej przyrody w kontekście Wspólnej Polityki Rolnej (Problems of nature protection in Poland in the context of Common Agricultural
Policy). Water-Environment-Rural Areas, (X-XII), 12, 4 (40), 111, 2012 [In Polish].

23. REY BENAYAS J. M., JAMES M., BULLOCK J. M. Restoration of Biodiversity and Ecosystem Services on Agricultural Land. Ecosystems, 15, 886, 2012.

24. CRIST T.O., PETERS V.E. Landscape and Local Controls of Insect Biodiversity in Conservation Grasslands: Implications for the Conservation of Ecosystem Service Providers in Agricultural Environments. Land 3, 699, 2014.

25. JANKOWSKA-HUFLEJT H. Rolno-środowiskowe znaczenie trwałych użytków zielonych (Agricultural and environmental role of the permanent grasslands). Problemy Inżynierii Rolniczej 1, 27, 2007 [In Polish].

26. JANKOWSKA-HUFLEJT $H$. The need of protecting permanent grasslands as a premise for the development of organic meadow farms. Journal of Research and Applications in Agricultural Engineering, 61 (3), 189, 2018.

27. PE'ER G., DICKS L.V., VISCONTI P., ARLETTAZ R.., BÁLDI A., BENTON T. G., COLLINS S., DIETERICH M., GREGORY R. D., HARTIG F., HENLE K., HOBSON P.R., KLEIJN D., NEUMANN R.K., ROBIJNS T., SCHMIDT J., SHWARTZ A., SUTHERLAND W.J., TURBÉ A., WULF F., SCOTT A.V. EU agricultural reform fails on biodiveristy. Science, 344 (6188), 1090, 2014.

28. KEMP D.R., MICHALK D.L. Towards sustainable grassland and livestock management. The Journal of Agricultural Science, 145 (6), 550, 2007.

29. HARDELIN J., LANKOSKI J. Land use and ecosystem services, OECD Food, Agriculture and Fisheries Papers. OECD Publishing, Paris, 114, 2018.

30. KLIMEK S., RICHTER GEN. KEMMERMANN A., HOFMANN M., ISSELSTEIN J. Plant species richness and composition in managed grasslands: The relative importance of field management and environmental factors. Biological Conservation, 134 (4), 565, 2006.

31. ŚWITEK S., JANKOWIAK Ł., ROSIN Z. M., SAWINSKA Z., STEPPA R., TAKACS V., ZBYRYT A., TRYJANOWSKI P. Jak zachować wysoki poziom bioróżnorodności na obszarach rolniczych w Polsce? Identyfikacja najważniejszych problemów badawczych (How to Keep a High Level of Biodiversity on Farmland Area in Poland? Identification of Major Research Problems). Wieś i Rolnictwo 4, (177), 130, 2017 [In Polish].

32. TÄLLE M. Conservation of semi-natural grasslands: Effects of different management methods on biodiversity Department of Physics, Chemistry and Biology Division of Biology Linköping University, Sweden Linköping, 74, 2018.

33. LANKOSKI J. Alternative Payment Approaches for Biodiversity Conservation in Agriculture", OECD Food, Agriculture and Fisheries Papers, No. 93, OECD Publishing, Paris, 2016.

34. WILSON J.D., WHITTINGHAM M.J., BRADBURY R.B. The management of crop structure: a general approach to reversing the impacts of agricultural intensification on birds? IBIS, 147, 455, 2005.

35. TRYJANOWSKI P., KUŹNIAK S., KUJAWA K., JERZAK L. Ekologia ptaków krajobrazu rolniczego (Ecology of agricultural landscape birds). Bogucki Wydawnictwo Naukowe, 390, 2009 [In Polish].

36. ATKINSON P.W., FULLE R.J., VICKERY J.A., CONWAY G.J., TALLOWIN J.R.B., SMITH R.E.N., HAYSOM K.A., INGS T.C., ASTERAKI E.J. Influence of agricultural management, sward structure and food resources on 
grassland field use by birds in lowland England. Journal of Applied Ecology 42, 932, 2005.

37. RUNOWSKI H. Poszukiwanie równowagi ekonomicznoekologicznej i etycznej w produkcji mleka (Searching for economic-ecological and ethical equilibrum in milk production). Roczniki Nauk Rolniczych, Seria G., 93, (2), 20, 2007 [In Polish].

38. BORECKA A., SZUMIEC A. Ekonomiczna efektywność ekologicznego chowu bydła mlecznego. (Economic effectiveness of organic dairy farming). Wiadomości Zootechniczne R. LI, 3, 95, 2013 [In Polish].

39. Rynek mleka stan i perspektywy. Instytut Ekonomiki Rolnictwa i Gospodarki Żywnościowej-PIB, ARR, Ministerstwo Rolnictwa i Rozwoju Wsi (Milk market state and perspective. Instytut Ekonomiki Rolnictwa i Gospodarki Żywnościowej-PIB, ARR, Ministerstwo Rolnictwa i Rozwoju Wsi ), 2018 [In Polish].

40. SOBCZYK M. Statystyka (Statistics). PWN Warszawa, 2005 [In Polish].

41. FAN X, LIU J, CHEN J., ZHAO L., HONG W. Changes of Land Use and Functions of Ecosystem Service: A Case Study in China. Pol. J. Environ. Stud. 28 (1), 73, 2019.

42. WANG X., DONG X., LIU H., WEI H., FAN W., LU N., XU Z., REN J., XING K. Linking land use change, ecosystem services and human well-being: A case study of the Manas River Basin of Xinjiang, China. Ecosystem Services. 27 (A), 113, 2017.

43. GRODZIŃSKA-JURCZAK M., STRZELECKA M. Effectiveness of Nature Conservation - A Case of Natura 2000 Sites in Poland. Protected Area Management, 183, 2012.
44. BRZANK M., PIEKUT K., DĄBROWSKI P., PAWLUŚKIEWICZ B. The Succession and Regression of Plant Species on Lowland Hay Meadows in Poland. Pol. J. Environ. Stud. 28 (3), 1577, 2019.

45. Pogłowie krów mlecznych według województw w grudniu 2018 roku. GUS 2018. [Population of dairy cows according to provinces in December 2018. CSO 2018] 2018. [In Polish].

46. BÓRAWSKI P., ZALEWSKI K. Czynniki kształtujące produkcję mleka w Polsce na tle UE. (Factors Shaping Milk Production in Poland vis-à-vis the European Union). Zeszyty Naukowe SGGW w Warszawie. Problemy Rolnictwa Światowego 18 (33), 3, 40, 2018 [In Polish].

47. SEREMAK-BULGE J. Rynek mleka stan i perspektywy (Development of milk market state and perspectives). Zakład Badań Rynkowych IERiGŻ-PIB, Warszawa, 2015 [In Polish].

48. CIEŚLAK K., PAWLEWICZ K., PAWLEWICZ A. Sustainable Development in Polish Regions: a Shift-Share Analysis. Pol. J. Environ. Stud. 28 (1), 265, 2019.

49. BRODZIŃSKA K. Problems of Biodiversity Conservation in Polish Agriculture. Agroecology and Sustainable Food Systems, 39, 158, 2015.

50. DREJERSKA N., GOŁĘBIEWSKI J. The Role of Poland's Primary Sector in the Development of the Country's Bioeconomy. Rivista di Economia Agraria, Anno LXXII, 3, 321, 2017.

51. WIGIER M. Changes in the Polish Agriculture in the light of the CAP implementation. Zagadnienia Ekonomiki Rolnej Suplement 4, 2014. 